\title{
Indian and Russian Literary Mutuality
}

\author{
Abhai Maurya \\ former Vice-Chancellor \\ The English and Foreign Languages University \\ Hyderabad, India
}

\begin{abstract}
The paper analyses the principal tenets of the method of comparative study of Literature and its evolution, applies insights into the history of cultural and literary interactions between Russian and Indian spiritual and aesthetic impulses depending on the socio-political vicissitudes in the two countries in different historical epochs, and substantiates their long-established literary mutuality.
\end{abstract}

Keywords - comparative literature; Indian literature; Russian literature; cultural parallelism; literary school; literary mutuality

\section{INTRODUCTION}

While dwelling on this theme, we can ill afford ignoring the basic tenets of the method of comparative study of Literature. At the initial stage of the evolution of the theory and practice of comparative study of literature many researchers were overwhelmed by the enormous data and material about interliterary contacts. They got as if submerged in the ocean of information about interliterary links, contacts, similarities, and reactions etc. which were taking place the world over. That is presumably why collection of this "dazzling data become an aim in itself for them. This passion for "factography" generated several negative trends in this new field. Firstly, this trend landed the comparatives, in the words of I. Gorky, "in a sort of labyrinth owing to their wild goose chase for facts to such an extent that they did not know where to stop and what quantity of concrete observations to collect" [1].

Such an empirical practice is responsible for the birth flourishing of a whole school of comparative literature, i.e. the French school, which is based on the "theory of influence, "theory of impacts" and "theory of borrowing". It is understandable that in the early stage of comparative study of literature these theories, which were essentially too Eurocentiric in their character, had their sway for a considerable long span of time. Moreover, the initial contribution of these theories and practice is undisputable. But such notions very often used for non-literary and speculative political ends.

What was, however, needed that these facts of interliterary contacts should have been used to determine and define the laws according to which the interactions between different literatures take place. An empirical exercise of collection and producing facts about one literature influencing another, exerting some impact on it, more often than not becomes a barren proposition, which may be fraught with dangerous political prospects with potentials to perpetuate the obnoxious superiority or inferiority complex among the comity of literature. This may result into propagating and practicing literary and cultural apartheid, which for all of us who are assembled here, should be the most abominable development.

\section{HISTORICAL RETROSPECTIVE ON THE RUSSIAN AND INDIAN CULTURAL AND LITERARY INTERACTION}

In the present context my main hypothesis consists in the fact that in the history of cultural and literary interactions between Russian and Indian spiritual and aesthetic impulses flowed to each other depending upon socio-political vicissitudes as they obtained in the two countries in different historical epochs. Indeed, the direction of these currents was determined mainly by two factors: the richness of accumulated cultural, philosophical and aesthetic treasure on the one end and the preparedness, rather eagerness and capacity to actively receive the incoming currents on the other. In other words the receiving side must fulfill two preconditions in order that the impulses flowing to it are effectively imbibed and assimilated into its own aestheticocultural ethos: firstly, it must achieve a certain level of development in its aesthetico-literary culture and, secondly, it must have a definitely conducive or borrowing is possible without the target literature being prepared for such receptions. The views of the founder of the Russian comparative literary school A. N. Vesyolovsky are quite relevant here. His concept of "cultural parallelism" and "reciprocal currents" had envisioned that borrowing of literary elements from any literature is possible only when the receiving literature has adequately conducive conditions for the elements being received. "Borrowing pre-suppose a conducive and receptive meeting ground for motifs and plots coming from outside" [2]. Elsewhere he states: "Borrowing does not take place in vacuum. It requires a reciprocal current, identical mode of thought and analogous imagery" [3].

In this background it may be stated that in the prerevolution period of Russian culture and literature right up to last days of Leo Tolstoy (say around 1909-1910) the flow of impulses had been from India to Russia as the latter was actively engaged in the quests for her own spiritual personality, identity and perspective. Moreover, at this stage the Indian side lacked initiative to seek inspiration from the Russian counterparts. An exhaustive account of the impulses flowing to Russia or of "the image of India" as 
obtaining in Russia from "Ancient Russ" to the contemporary times has been given by G. Bongard-Levin and A. Virechshagin in their monograph The Image of India [4]; by Academician Y. Chelishev and A. Litman in their book Traditions of Great Friendshi [5]; by A. GnatyukDanilchuk in the book Tagore India and Soviet Union - A Dream Fulfilled [6]; by A. Shifman Tolstoy and India [7] and many others. A cursory glance on this process may be imperative.

India finds a mention in the ancient most relics of Russian literature, for example, in the stories about "the marvellous bird from India, the phoenix, which lived near the "Sun-City" (Heliopolis)" [8]. The wonder world of animals of India found fascinating perception in Rus. In the literary relics of legends and lore of the olden times Rus India seemed "a magical kingdom full of mystery and beauty", which is borne out by the "Aria of the Indian Merchant Sadko" inspired by an ancient legend about a Novogorod merchant who undertook adventurous journey to distant India, a land of Wonders [9].

In 12th century the Buddha's biography found its transposition in The Romance of Varlaam and Joseph. Bongard-Levin and Vigasin are of the opinion that Joseph is derived from the Indian word "Bodhisattva" [10]. The above scholars are of the opinion that "a definite Indian influence" can be felt in "the famous religious verse Dove-Book (Golubinaya Kniga)" [11]. India finds a mention in some ecclesiastical Slavonic texts as well. Similarly, according to Bongard-Levin and Vigasin the work A Narrative of the Rahmans and their Amazing Life is about Indian Brahmans, Rahman being its distorted form of Brahman. The Story of Indian Kingdom... is another important work which led to the formation of a definite image of Indian in Rus. Similarly the story Alexandria (about Alexander the Great and his adventures in India) existed in several versions from 11th12 th centuries onwards. These stories perpetuated an image of 'Rich India" in Rus of those times which found extensive reflection in folklore traditions, in particular in the Russian heroic epics (bylinas) which is eloquently evident in the bylina about the hero Duke Stepanorich (an Indian) who astounded the Kievan prince Vladimir by the Wealth of India. The hero of the Nogorod bylinas, the above mentioned merchant Sadko, undertakes a business trip to 'rich' India. Similar account of journey to India is found in 17th-18th century bylina (journey of Mikhail Potuk to India). Bongard-Levin and Vigasin are also of the view that the story Stephanites and Ihnelates, emanating from Indian stories Panchtantra, found currency in 15 th century Rus.

The accounts of journeys to India bear a definite testimony to keen interest that was displayed by the Russians towards India from the earliest times. Many Russian travellers undertook arduous voyages to reach the 'enchanting' land of India. But not many could leave the trace of their adventures as their footprints and tracks got buried under the avalanches of Russian snow or Indian sand storms. The only surviving account of such a journey is Afanasy Nikitin's A Voyage Beyond Three Seas (1475) - a travelogue of this merchant from Tver about his visit to Indian from 1471 to 1474 .
The 16th and 17th centuries witnessed a significant growth of trade between Indian and Russian merchants. However, this historically established phenomenon does not find ample reflection in the literary works of Russia created during this period. Yet some stray visitors did leave behind their impressions of India in the form of "sketches" and notes in the diaries. After the establishment of Academy of Sciences in Russia in 1724 the academic interest in India got a definite Philip. There is concrete evidence that Daniel Messerschchmidt learnt to read, write and speak Hindi as well he gained slight acquaintance with Sanskrit. One of the "first scholars to work on Indian languages was the orientalist professor George Jacob Kehr" [12], who studied grammar and spoken language and through who Academician Theophil Siegfried Bayer got an access to his Sanskrit teacher which information is recorded in Bayer's works History of Greco-Bactrian Kingdom, wherein there is an article on "Brahmana, Tangut and Mongolian written Language". Towards the end of 18th century Academician Pyotr Pallas created his Comparative Dictionary of World Languages, wherein there is information about Sanskrit, Hindustani, Bengali, Multani and even about the languages of Dravidian family like Telugeu, Tamil and Malayalam. Simultaneously with this the Russian publishers tried to enlighten the Russian readers by publishing latest European works on India, an example of which is the Short and General Explanations and Discourse on the Manners, Habits, Language, Faith and Philosophy of Indian published in 1789 [13]. This period is also marked by enhanced journalistic interest in India.

The 1780's and 1790's witnessed a very keen interest evinced in India by the democratic representatives of Russian Enlightenment as well by the first harbingers of Russian revolution, i.e. by Nikolai Novikov and Alexander Radishchev who in his Song of History writes: "These descendents of wise Brahmans, Prisoners of insolent villains (The British - A.M.) in their turn preserve their sacred law in the Yajurveda, which had been written in the letter of ancient Sanskrit, and is the embodiment of their ancient glory and witness of their shame!" [14].

In 1788 , there appeared the first translation of Bhadavadgita or as it was called Bhagavat-geta or conversations of Krishna with Arjuna with a commentary translated from English version into Russian. The eminent Russian historian and writer, Nikolai Karamzin translated Kalidasa's Shakuntal into Russian in 1792 and provided it with a remarkable preface: "The creative spirit does not lie in Europe only, it is a citizen of the Universe. Man is everywhere a man, everywhere he has a sensitive heart and in the mirror of his imagination he holds both Heaven and Earth." Karamzin in Kalidasa's drama found "the greatest beauty of poetry, gentle feelings, inexuisite and ineffable tenderness... the purest, inimitable nature and great art" [15]. Karamzin compared Kalidasa to Homer.

Herein after numerous Russian writers and poets turned their attention to Indian literary works, translated them and in the process derived inspiration to such an extent that they created their meant rusification of Indian impulses. An eloquent example of this phenomenon is the introduction in 
verse written by the eminent Russian poet Vasily Zhukovsky to his translation on "Nala Damayanti" [16]. This poem is a amazing piece of creative work which is replete with Indian motifs, metaphors, similes, allegories and landscapes, be that the beauty of Kashmir Valley, radiance of Indian dawn, fleeting glimpses of an Indian bride, amazement at star-studded sky or glitter of a royal palace and so on. The poet cherishes the fantastic images, enchanting scenic glimpses in the "evening" of his life, which is warmed up by the spell of the nostalgic memories and he offers them the fragrant flowers of his poetry. Undoubtedly, this is a unique example of how the process of translation often spur up creative imagination in the poets and writers, which, in turn, lead to incredible cultural blending and congregation.

There are numerous examples in Russian literature, which could substantiate the above point beyond any shred of doubt. The above-mentioned Indian epic work "Shakuntala" was translated by Wolcott in 1786. This translation reached Russian poets as well, though not without torturous zigzags. But, more importantly, this led to the generations of creative impulses in Russian poets, which is borne out by the forceful poem "Skontala", written by one of the powerful poets of Russia in 1847, i.e. Afanasy Fet. To this very phenomenon owe their origin a small poem by Apollon Maikov "The Girls, Bathing on the Banks or the Ganga" (1862): poems by Semyon Nadson "Three Nights of Buddha" (1885), "Three Meetings of Buddha" (1885); poems by Konstantin Balmont "Maya" (1899), "Indian Motif" (1899), "The Wise Indian"; poem by Valeri Bryusov, and Ivan Bunin: "Agni" (1903-1906); "The Indian Ocean" (13.11.1916) and others. We particularly mentioned those poets who in most cases, did not have a possibility of having a direct "genetic contact" facilitated by translation as a medium and form of interliterary communication, i.e. thanks to translation's being a catalyst in cross-cultural intermingling.

Even the great Russian poet Alexander Pushkin shown a keen interest in the classical Indian literature, Ramayana which, in fact, was mentioned by him in his correspondence with the Russian Decembrist philosopher Chaadaev.

The revolutionary democrats - writers, poets and critics - in particular Belinsky, Cheknyshevsky and Dobrolnbov were exercised about the plight of Indian as they had extremely high regards for Indian cultural values and spiritual ethos.

The contemporary Soviet Indologists like G. BongardLevin, A. Vigasin, Y. Chelishev, A. Gnatyuk-Danilchuk and others have give exhaustive account about the scholarly work done by the Russian and Soviet Indologists on various aspects of Indian culture institutions as they obtained during the many centuries long Indian history. By all reckonings, the work done by Soviet Indologists is simply stupendous as its vastness and depth will astound any Indian, who would take pains to get acquainted with it. Indeed, the Indian scholars are yet to fathom the valuable work done by the Russian and Soviet Indologists. Recently and overview of this work, encompassing only some general contours has been published by Prof. R. K. Megh under the title "Role of Soviet Indology in the Cultural Leap in Asia" [17]. Here there is no scope for delving deep into this aspect. However, mentioning some of the important landmarks may not be out of place.

Gerasim Lebedev, who came and stayed in India during the years 1789 to 1797 , laid the foundation of systematic study of various aspects of Indian culture. He found the first professional drama in Calcutta and mastered the languages, philosophy and art of India. He was the first Russian to point out the affinity of Sanskrit with Slavonic languages. In the 19th century, particularly from 1818 onwards when teaching of oriental language was instituted in St. Petersburg, Russian Indology made rapid strides. The main thrust areas of these studies were comparative study of Sanskrit and Slavonic languages, Language of India, Buddhist Studies, Indian Philosophy, literature, historical events (like the uprising of 1857), art and what have you. It is difficult to enlist here all the Russian scholars of Indian studies as their name is logion. However, the contribution made by I. P. Minaev, F. Shchelbatskoy deserve a special mention. Quite significant contribution was made by distinguished Russian artist V. Vereshchagin (1842-1904) who visited Indian twice (1874-1876) and (1882-1883) and made around 150 sketches on Indian motifs which, in their turn, became the subjects of other artistic and literary works on other Russian creative personalities. The most significant contribution in this field, of course, was made by Nikolai Roerich, whose name is a legend in this respect.

We attempted briefly to survey the process of India evoking interest of Russian culture, literature and scholarship with a view to drive the point home that till about the beginning of 20th century the currents mainly flowed from India to Russia. They reverse current, if any, was extremely feeble. One main reason for that, among a host of others, lies in the fact that the exponents of Russian culture, literature and art took bold initiatives, made arduous efforts, faced grim ordeals in order that the treasures of Indian wisdom could be made accessible to Russian people. This, of course, speaks volumes about the openness, farsightedness and a quality and capacity of the Russian people to appreciate what is good in the world treasure of culture.

\section{SPECIAL CONTRIBUTION OF TOLSTOY INTO POPULARIZATION OF INDIAN CULTURE IN RUSSIA}

In the first decade of 20th century, many Indians began corresponding with the Russian "Titan" in the realm or literature, i.e. Leo Tolstoy. It is, however, true that the acquaintance of the Indian with Russian literature and in particular with Tolstoy's works began in the seventies of the 19th century as work of Russian literature began to reach India via England. But the wider Indian reader got to know Tolstoy only in the first decade of 20th century, which is explained by the interest of Indians in Russia heightened by the Russian Revolution of 1905. The interest of Indians in Tolstoy was also aroused, firstly, by the writer's great concern for the plight of Indian's his deep preoccupation with Indian philosophy (Vedas and Vedanta), epics 
(Ramayana, Mahabharata), folk literature (fables and legends from Panchatantra and Hitopdesha) and Buddhism. Secondly, Tolstoy's stature and moral authority had reached such heights that the Indians, particular those living abroad, despite the barriers put up by colonial regime, gradually got to know about him. Tolstoy was particularly exercised over the ethical philosophy of Buddhism. He wrote several essays and a long legend "Karma" in 1894. Buddhism, indeed, remained a subject of life long quest for Tolstoy. Tolstoy displayed a keen interest in the philosophy of Shankaracharya, Ramakrishna Paramhansa, Swami Vivekananda, whose socio-political views were quite radical for instance, his statement: "First bread, then the religion. We stuff the poor with too much of religion while they want to eat... As long as there is even one dog which does not have food in my country, my religion is to feed it" [18].

Tolstoy displayed genuine concern for the miserable plight of the Indians under British regime. When the news about the British repression in 1858 reached Tolstoy, he had no hesitation in calling it "the brutality of Great Britain" [19]. He condemned the British when they incarcerated Vivekananda and called upon Indians to offer peaceful noncooperation to the colonial rulers. Precisely this emboldened numerous Indians to write to him. His first Indian correspondent was A. Ramseshan (1901) publishers of a socio-political journal - The Aryan from Madras. Among other things, this author conveys to Tolstoy the Indian reader's reaction to Tolstoy article "About Life", which means that Tolstoy work had gained some currency among Indian readers already at that time. Further, the author spoke about the exploitation of his country by "foreign capitalists". Tolstoy replied to this letter on 25th July, 1901 which was published in the August (1901) issue of The Aryan, which got a wide publicity and ready response in India society. Then a chain of Indian correspondent developed (Mufti Muhammad, Sadiq, publisher of a Lahore journal Review of Religions; the well known philosopher Baba Parmananda Bharti, publisher of Tolstoy in 1905, which got a reply from him on February 16, 1907. An eminent advocate of Madras, Mr. Gopal Chetty, editor of the journal "The New Reformer" corresponded with Tolstoy from May, 1907 onwards and he published from Madras a book called Count Leo Tolstoy, His Life and Teachings which was one of the first Indian books on Tolstoy. In this book the author writes about the "powerful influence of Tolstoy's letter (artistic images in India [20]. Chatty published Tolstoy's letter (his reply to Gopal Chetty's letter) in his journal "The New Reformer", which generated more Indian admirers of Tolstoy and more letters started pouring in to him from them, one of them being from professor Rama Devi, the editor of the journal "The Vedic", which he sent to Yasnaya Polyanna. Tolstoy read the journal and replied to Rama Deva's letter asking for Indian books on or about Vedas about which Tolstoy wanted to write and publish a book for Russian readers. The other Indian correspondents of Tolstoy, who should deserve a mention here, are Abdullah-alMamun Suhrawardi, a jurist and publisher (from London) of the journal "The Light of the world", (he wanted to translate Tolstoy's works into Bengali "beginning form Resurrection which enjoyed world fame" [21], one R. M. Das Sharma, a scholar of ancient Indian Philosophy S. R. Chittal from Bombay (he compared Tolstoy "to the greatest thinkers of India" [22]; the editor of "Brahti Marga Sahib" from Banglore, a lady (Minni Robinson) editing a Calcutta journal and Vaidyanatha, a publicist from Madras. In their letters they noted "the great popularity of his work in India and their influence on the Indian intelligentsia" [23].

The flow of letters to Tolstoy from the Indians increased manifold after the publication in the world press of his famous pamphlet "I cannot Remain Silent" in 1908. The most prominent among his new crop of correspondents was an Indian militant patriot Taraknath Das, publisher of the journal "Free Hindustan" from Vancouver (Canada). It is in reply to Taraknath Das's fiery letters that Tolstoy began writing on June 7, 1908 his famous "A Letter to a Hindu (Indian)" which he wrote for more than six months (29 versions consisting of about 413 sheets were written before the final version was sent). This "letter" (or book) contains the quintessence of Tolstoy views on the Indian situation, immoral forms of social order in which the English and other pseudo-Christian nations live today", his concept of peaceful non-cooperation, in short, both the strong and weak points of Tolstoyan philosophy. This Letter was published by Taraknath Das in 1909 and, as was expected, it evoked the most agitated reaction from Taraknath Das himself as he published in India "An Open Letter to Count Leo Tolstoy in reply to his "Letter to an Indian". Of course, in this pamphlet Das appreciated Tolstoy's support for the struggle of the Indians, his idea "of a society in which there would be no oppression of man by man" [23]. But he firmly rejected the idea of non-resistance to evil by force. All this notwithstanding, the "Letter to an Indian" earned Tolstoy the most valuable correspondent, Mohandas Karamchand Gandhi, who wrote his first letter to Tolstoy on October 1, 1909. After this, there was no looking back on the correspondence between the two giants of our times, which, of course, is a matter of well documented history and we may do without dwelling on it in details. But the most important fact to note here is that Gandhi published "The Letter to an Indian" with his very positive introduction apart from in English even in translation into Gujarati also, which created a spate of Indian letter writers to Tolstoy during his last year in life.

The most important fact that needs to be underlined is that he made an enormous contribution in popularising Indian culture in Russia: "Tolstoy was particularly concerned in those years (last days of his life - A. M.) with acquainting Russian children with India. He considered that Indian poetry and wisdom would not only be interesting but useful for Russian children" [24]. That is why in his series of "Book for Reading" and "ABC Book" he re-wrote the essay on Buddha, translated and adapted numerous Indian fables, legends and parables (from Panchatantra, Hitopdesha and Tamil literature "Kural") for publication in his above series. In his "Circle for reading", "The Thoughts of Wise Men" and other works collected under the title "Indian Wisdom" he incorporated may sayings, proverbs and aphorism from the Vedas and the Upanishads. Tolstoy. However, took care to make Indian works and motifs 
effectively understood and assimilated by the Russian readers. That is why he carefully adapted the Indian fables and fairy tales to Russian perceptions and sensibilities: "This is why, as Alexander Shifman observes, in place of Indian gods, rajahs, Brahmins, and merchants, traditional Russian folk heroes, forest and water spirits, stupid tsars, swindlers and shrewd forest peasants figure in them though in majority of fables the Indian color has been retained" [25]. A great act of cross-cultural synthesis, indeed!

\section{UPSURGE OF INDIAN AND RUSSIAN INTELLECTUAL AND LITERARY MUTUALITY}

The upsurge witnessed in the beginning of 20th century in the flow of mutual currents between Indian and Russian intellectual and literary currents was explained by the simmering and heightening of revolution movement in Russia and freedom struggle in India. Many Indian intellectuals were corresponding not only with Tolstoy but with prominent literary figures like Maxim Gorky (Krishnavarma Ran Sahib and Madam B. R. Cama who headed a group of exiles in Paris). The first Russian revolution of 1905 got wide publicity in Indian press, rigours of colonial censor notwithstanding, No less actively Indian press reacted to Tolstoy's death in 1910. In short, on the eve of October Revolution 1917 the spiritual and intellectual flow between Indians and Russian had become extremely active and vibrant. The Great October Socialist Revolution of 1917, undoubtedly, was the most spectacular event in the galaxy of sagas and feats of valour accomplished by the Russian people in the whole history of mankind.

The initial response to October Revolution by the Indian writers was that of an exalted euphoria. This was no simple change of power of replacement of one ruler by another. It was the most decisive turning point in the history of mankind which meant that world would not be the same ever again hereinafter. New horizons, new vistas, new visions were thrown open to the entire mankind in the aftermath of the October Revolution.

The reverberations of the October Revolutions swept the world like a hurricane. India could have been no exception particularly at a time when the fighters for her independence discovered new dimension, new contours and new perspectives for their struggle: poets found new motifs, new notes, new tones, new rhymes for their poetry:

"I reject the old laws...

Shatter the chains in which a slave is fettered",

thundered one poet;

"Glory to all the downtrodden,

Glory to ever new uprising" -

wrote another.

Subramania Bharati, the outstanding Tamil poet compared the Revolutions with Indian mythological forces that combat and destroy evil from the face of earth. Nazrul Islam, a well-known Bengali revolutionary poet called upon his comrades:

"Wake up brother,

Welcome the new mother."

Prem Chand, the great Hindi writer in October saw the dawn of "new era in the history of mankind" [26]. The famous Urdu poet Iqbal addressing the workers wrote:

"Arise that the world had taken a new turn.

Your era has dawned in the East and West."

Bal Gangadhar Tilak, a towering freedom fighter, viewed the October Revolution as "a symbol of the war against tyranny and oppression" [27].

In the aftermath of the October Revolution, the struggle for the independence of India acquired qualitatively new perceptions and dimensions. Book like Mother by Maxim Gorky got smuggled into India by dauntless revolutionaries. These were devoured by them in the grim conditions of their underground life. The legendary revolutionary Bhagat Singh, who was put on trial by the British rulers after he had thrown a bomb in the Central Legislative Assembly, delivered a powerful speech in the court which bore a striking resemblance to the speech of Pavel Vlasov, the hero of Mother. Subsequently when Bhagat Singh was imprisoned in the British prison he avariciously read literature smuggled out of the land of revolutionary Soviet. No wonder, when this indomitable young revolutionary was to be taken from his prison cell to the gallows for being hanged he was reading one of Lenin's works (State and Revolutions) and when the policemen ordered him to leave he is believed to have quipped: Wait, a revolutionary is meeting a revolutionary."

And this is no fiction. Hundreds of Indian fighters for independence drew immense inspiration from the land of Soviets. The shining example of this is the declaration of the Bhagat Singh's party "Hindustan Samajwadi Revolutionary Army" (Indian Socialist Revolutionary Army), which said that freedom for them did not mean driving away the white Sahibs (masters) and replacing them by the black ones. Freedom for them meant abolishing the system under which a man is exploited by man. Hence, already in early 1920 s they chalked out a programme to usher in the socialist revolution in India.

However, a more sober look at the phenomena that are discernible in the post October Revolutions Indian Literature, would reveal that the October Revolution, and in particular Russia literature had much deeper impact on Indian literature than the mere euphoric reactions, it must be mentioned here that, firstly, having received the initial impulses the most Indian literatures chartered out their own course in a most original manner in its further assimilation and regeneration. Secondly, these impulses travelling to Indian literature were readily accepted, because they found a conducive meeting ground in the Indian soil. Our earlier observations about the implications of theory of impact and influence should be viewed dialectically. It needs to be stressed that to totally negate the role of "influences", "impacts" and literary "borrowings" in inter-literary cross- 
currents will be entirely inconceivable and will be tantamount to another absurd extreme. Just as people learn from each other in life in various ways, different literatures also get immensely benefited from the experience of their other another counterparts. K. Marx gave an apt formulations in this connection: "Each nations can and must learn from each other" [28].

In the history of different literatures, there are numerous examples of writers, poets experiencing impact of other literary figures or works of other literatures. There are countless examples of the formation of the entire aestheticconceptual framework of a writer under the impact of impulses or spiritual impact coming from outside the frontiers of national literatures. Even within the limits of national literatures such a phenomenon is no rarity: "In the history of world literature there has been not a single poet who in one way or the other did not experience the influence of his or her predecessor. Impact is one of the stepping stones on way to ascendancy to the heights or originality" [29].

What is true of individual writers could be fully applied to any national literature as well.

"Influence" or "impact", therefore, should not be a stigma as it, in the words of P. N. Berkov, "is neither something shameful nor disgraceful for a writer or a literature. It is only one of the forms of development of a literary personality or literary process" [30].

But it, continues Berkov, becomes "shameful and disgraceful" only in that case when a writer or a literature does not utilize "influence" as an instrument for revealing and evolving their own originality and confine themselves to mere imitations and dependence" 31 . Further the eminent theoretician adds that "history of world literature does not know a single case when a literature really remained only an imitative one for all times to come" [32].

It will be worthwhile to broadly classify the planes on which the Russian literature interacted positively with Indian literature rather than mentioning the cases of individual writers imbibing in one way or the other currents flowing from the literature of the land of the revolution.

In the early 1920's many Indian writers almost parallel with some Russian writer and poets and poets (Lydia Seiphullina, Artyom Vesyolyi, Vsevod Ivanov and others) in their writings give a direct depiction of revolution in the form of a all-sweeping hurricane. In Nirala's poem Torrent (1921) the torrential streams sweep everything decrepit and decaying on its way. In its tempestuous velocity there is a definite allusion to the life getting revolution and revitalised. This very note is audible in the poems of the Bengali poet Nazrul Islam with ever ascending crescendo. For example, in the poem The Rebel the poet is all set to demolish all the oppressive structures.

\section{I am the Great Rebel}

I Shall become quiet only when, the sky and the wind are filled no more with the agonised wail of the oppressed...

In a fiery editorial published in his Bengali biweekly

\section{Dhumketu ( The Comet) Nazrul writers:}

"The flood that has swept away into oblivion that prison house of millions in Siberia... the roar of that flood is at your gate" [33].

One significant result of such a phenomenon manifested in the fact that, in Ashish Sanyal's words, it "rejuvenated old literature, pouring life blood into it" [34].

The image of new dawn symbolising the end of the grim darkness of colonial enslavement marked many works of Indian literature. This is particularly true of the writers and poets of revolutionary romantistics trend. Sunrise of Sumitranandan Pant, Song of the Thundercloud (1920) of Suryakant Tripathi Nirala, Let the Dungeons Perish (1920) by Josh Malihabadi, an Urdu poet could be cited as examples of this phenomenon.

The anti-imperialist, anti-British mood of Indian writers got a gigantic philip thanks to October Revolution and its authentic mirror, the Russian literature, which by inherent character gave a tremendous boost to the "national liberation movement of a new type" [35]. From the very inception the Soviet government asked the imperialist powers to grant independence "to the peoples of Ireland, Egypt, India, Madagascar, Indo-China etc. as the Russian Revolution has done with regard to Finland, the Ukraine, Byelorussia etc.”. [36] Indian writers naturally looked upon the October Revolution "in the context of liberation movement in India" [37].

As the time passed, the Indian literature began to reflect more serious and balanced appraisal of the revolutionary changes which had a salutary manifestation in the works of romanticist writers. The Chayavadi (romanticistic) trio of Hindi literature, i.e. Nirala, Prasad and Pand came down to mother earth from the soaring flights in the realms of all blue. They began to depict the down to earth reality. But in the literatures, which had lagged behind in terms of development, revolutionary romanticism made rapid strides. A case in point is Telagu literature, wherein romanticist movement, according to D. Anjneyulu [38], spearheaded by D. U. Krishnasastri, developed in 1930s.

In Gorkian realism the conception of humanism is not a mere slogan, as Ibsen put it, 'about a man in general'. It is an aesthetic principle, a basic position according to which a writer retains an innate faith in the positive potential of man. It is an active or militant humanism, which is radically different from abstract or passive humanism. Its inherent optimism helps a man in preserving finer human traits under all circumstances whereas pessimism breeds cynicism, frustration, hopelessness and alienation. An actively humanists intervenes effectively on the side of suffering people by struggling for the eradication of root causes of the human misery. Thanks to such an approach, consciousness takes the place of despair and dismal ennui in a dejected man. Organised, conscious preparations for revolution and revolutionary action replace spontaneous outbursts and eruptions. Out of a chaotic, dissipated, disjointed, deformed and inane creature in human flesh, a kindled, awakened, inspired and upright man is born, who is full of confidence, 
purpose and place in life. Portrayal of rejuvenated man retrieved from the abysses of both subjective and objective nature more than fulfils the aim of art, which helps in redeeming, enlightening and straightening up of a human personality.

As the turbulent perception in Indian Literature of the October revolution and revolutionary Russian Literature got stabilised in the form of an in-depth appraisal, the Indian literature in this process acquired a definite maturity in terms of character portrayal and its conception of man and humanism. Gorky is hymn to man, his most vociferous condemnation of downgrading man found recurrent and resounding echo in Indian Literature. "Man is not a slime underfoot as the upper classes find it convenient to see him. Man is a miracle, the only miracle on earth, all the rest is an outcome of his will, his reason, his imagination". Such as the forceful Gorkian conception of man and the Indian literature, in particular, from 1930 onwards proved its validity most convincingly. This is what the character of a nameless outcast Manu from Coolie (1935) of Mulkraj Anand and Premchandian characters drawn from the lower depths of the society prove. The writers started creating remarkable characters drawn from amongst the poor peasantry and exploited working class. Premchand's (Hindi) peasant heroes, Josh Malihabadi's (Urdu) "Kisan", Sadat Hasan Manto's "Tongawala", Tarashankar Banerjee's (Bengali) tribal and semi-tribals, Kosaraju Seshaiah's (Telugu) landless agricultural workers, Mama Varerkar's (Marathi) factory workers, the ardent fighters of classstruggle depicted by Surender Singh Narula (Punjabi) in his novels ("Lok Dushman"...), Porhiyats' (Labouerers) of Bewas (Singdhi), "Hari Haqdars" (Tiller-the rightful owner of the Land) of Gulrajani (Sindhi) could be cited as forceful examples of the process of democratisation of Indian Literature that took place in 1930's. Niranjan Mohanty has rightly observed that the Russian Literature and the Revolutions "become the symbol of common man. It ushered in new ideas, shaped new beliefs and trained Indians to fight for freedom, fraternity and equality" 39.

In the background of the Russian revolutionary literature the Indian literature acquired a definite sense of direction and commitment. In Russian Literature a writer of socialist realism was required to actively participated as part of the mainstream trying to both "interpret and change" (M. Marx) life. Lukacs links the activeness of a writer with the question of "receptivity and sensitivity of the artist" which had been totally distorted by modernist writers, who reduced its essence to "passive mirroring" of things and divorced it from activity and practical involvement of a writer. "Such writers experience only themselves. For them receptivity means listening to their own inner sensations, to the experience of their own ego... their so-called receptivity is merely passive contemplation of their won novel"observed Lukacs [40]. In the background of such deep going changes that were underway in Russian literature it was no longer possible to get away with creating the art for art sake or escapist or esoteric works in Indian literature as well. The exponents of decadent and modernistic literature were given a due drubbing particularly in the background of
Gordian poser: "Who are you with, Masters of culture?" or Mayakovsky's definition of a poet. In Niranjan Mohanty's words, "These mystics, without curing the fatal wound, would cover under the green tapestries so that the pain never reaches them" [42].

Another salutary development that took place under the invigorating currents flowing from the direction of Russian literature of manifested in the diversification of thematics and problematics that were tackled by the Indian literature. The themes of combating social problems like inequality of woman and man, widow remarriage, social justice etc. become recurrent plots of the most works of Indian literature

Lastly, we would like to return to the point that degree and depth of influence of any literature on another depends on the activeness and level of preparedness of receiving literature. Among the Indian literatures Bengali, Hindi and Urdu literatures responded most enthusiastically and congenially to the impulses travelling from the direction of Soviet literature. This only proves that they were better prepared to receive and assimilate the incoming currents.

Historically Bengali literature among the Indian literatures had the oldest revolutionary traditions. Indeed, the egalitarian and utopian socialist ideas got reflected in the Bengali writings already in the middle of nineteenth century, if not earlier. Gautam Chattopadhyay in his article of "October Revolution: Impact on Bengali Literature" gives a succinct account of revolutionary traditions of Bengali literature.

Already in 1842-1843 Radhanath Sikdar made a fervent appeal for the cause of toilers in the pages of Bengali Spectator. Bengali weekly Somprokash supported the call for the "8 hours working day" of First working Men's International of Karl Marx. The legendary Paris Communes of 1870-71 received as application from Calcutta seeking permission to start a Branch of Communes in India. In 1871 was started a journal Bharat Sramjibi" (Indian Working Men). In 1879 Bengali Novelist Bankim Chandra wrote his article "Samya" ("Equality") in which he lambasted the educated Bengalis for practising inequality on the basis of birth. Bankim Even opposed the private ownership of means for production and thus supported socialism albeit vaguely. Reverend Lal Behari Dey and Adhar Chandra Das took up cudgels on behalf of the peasantry and the toiling masses. Tagore and Vivekanand were also "musing over socialism"44 towards the end of the 19th century. Rabindra Nath Tagore supported the idea of the socialists to distribute wealth among all mankind. Vivekananda saw in socialism the only hope of India. Mahendra Nath Dutta, the second brother of Swami Vivekanand had envisioned India to be a "Toilors' Republic". Virendranth Cahttopadhayay (elder brother of Sarojini Naidu) and Abani Mukerji had become 'confirmed socialist' after coming into contacts with the socialists in Germany. Such was the fertile soil on which the seeds of October Revolutions fell and they began to germinate and sprout rapidly in this soil.

A great philip to the process of Bengali literature becoming a powerful vehicle of revolution was given by 
Tagore's Russiar Chithi. Tagore in his Letter from Russia (1930) described the changes taking place in the fields of educations, culture, literature, eradication of religious bigotry, of exploitation of man by man in the Soviet Union within a short span of 10-12 years more than half of which period had been eaten away by the wartime devastation and destruction. He described the positive changes taking place in the most glowing terms and at the same time described the western degenerate culture as a great scourge, monster and a source of human misery. These letters were published initially in Bengali press and subsequently in other languages in India, notwithstanding the callous British ban that was clamped on tem from time to time. We are of the considered opinion that Tagore's literary works, journalistic writings and pronouncements about the October Revolution and Soviet literature played a decisive role in making the Bengali literature and cultural-intellectual world more active and enthusiastic in receiving the incoming impulses from the direction of the land of October Revolution and post October Russian literature.

In Hindi literature the fertile ground for the seeds of October Revolution and literature to germinate and sprout up had been prepared by the democratic movements of earlier periods. Bhakti poetry had forced "God leave his heaven and come to earth in human form and thus be humanised" [45]. Bhartendu Harishchandra made vigorous efforts to bring Hindi literature closer to the people. Many Hindi writers had been actively participating or sympathising with the ever intensifying freedom struggle, contributing in the process to the democratisation and revolutionisation of the Hindi literary world. After the great socio-literary reformers like Kabir, Tulsidas, Surdas, Raidas the Hindi heartland had also been the scene of great events like the first war of independence of 1857. During the days of freedom struggle Allahabad, Benaras, Delhi, Lahore etc. had been the centres of great revolutionary activity (Meerut conspiracy case, revolutionary activities of Bhagat Singh and his comrades in Lahore and elsewhere in North India, Kakori conspiracy case etc.). Many of the writers (Yashpal, Shiv Varma, Vatsayan) had been direct participants in the revolutionary movements. Prem Chand's presence in the Hindi literature also, was quite receptive when the spiritual and aesthetic currents started trickling in from the first socialist revolution.

About Urdu literature's being extremely conducive and congenial to the currents coming from the Soviet literature I would rather quote Qamar Rais, an Scholer, who is of the view that literature is more susceptible to socialist ideas than their counterparts in other languages. They felt no qualms in accepting the revolutionary valves. A number of young Urdu writers pinned their faith on the concepts of economic and social equality and developed an enthusiasm for national independence. This ready acceptance of revolutionary values may be explained in many ways. In the first instance, the cult of mysticism and the Sufi poets of the 18th and 19th centuries had already established a strong tradition of revolt against the establishment and against all social and religious institution, which were supporting it. They had exposed the hypocrisy of the priestly class and the exploitation of the common people by the ruling classes. These healthy mystical values had already been a part of the poetic sensibility of Urdu writers, Secondly, certain enlightened thinkers and religious reforms like Shah Waliullah and Jamal-ud-din Afghani had also propagated through their teachings the concepts of national freedom and equality of men. Thirdly, Urdu writers were also exposed to the influence of national and reformist movements, which fostered patriotic and revolutionary tendencies. Lastly, the political conditions, obtaining in India at that time did not allow Urdu writes to be merely passive spectators, particularly at a time when the British government was resorting to ruthless measures for suppressing popular movement. This political situation created a strong reaction among the Urdu writers who were always willing to accept a revolutionary programme.

The political themes and the anti-British sentiments had already crept into Urdu literature through the writings of Shibli, Sajjad Hussain, Akbar Allababadi, Abdul Kalam Azad, Hasrat Mohani and Raj Narain Chakbast" [46].

A Brief account of when and how Gorky's novel "Mother" was translated into various Indian literatures will also corroborate our argument. It was translated into Bengali in 1925, into Hindi in 1929-30, into Telugu in 1934, Punjabi in 1940 and in most other Indian literatures in 1940's or so.

The changes generated in the realm of aesthetic principles and literary criticism could have been another aspect of our paper. But that could be a theme of another discourse.

Finally, we conclude our observation by citing the view of an eminent Bengali literary scholar Gopal Haldar about the broad planes on which the Great October Revolution and Russian literature interacted with Indian literatures with which I find myself in general agreement:

(1) Russian literature has re-awakened our faith that literature has a purpose - it is not a juggler of words and ideas, an idle pastime. It is at once an essay in creation and must re-create in its turn.

(2) Russian literature gives our readers and writers a sense of belonging. Everybody need not be "Committed" to socialism or class war, but nobody can lead a life of social alienation without injury to his own soul and without losing his own heritage.

(3) It is a literature for actual action for socialist life, and for acceptance of life and reality, emphasising the dynamic process leading to higher possibilities - a literature against all obscurantism and shibboleths and exploitation and oppression.

(4) Lastly, and above all, Russian literature reveals the miracle of man, man as the hero of history and measure of all things, and reveals humanism in its true character. It embodies the old gospel of "liberty, equality and fraternity" in more concrete terms, and gives it newer dimensions" [47].

The process of inter-literary intermingling and confluence of Indo-Soviet minds got a gigantic impetus after India won freedom in 1947 and the two countries 
established diplomatic ties even before that. Towards the end of the 1950s and thereafter the cultural exchange between the two nations witnessed an unprecedented spurt and buoyancy.

The process of the cultural resurgence of the two countries is finding a natural culmination in the present festivals of culture in the two countries.

\section{CONCLUSION}

Today the land of Soviets is in her new resurgent mood. The eyes of the entire mankind are once again directed at what is happening in the USSR. No doubt, refreshing winds are blowing from the land of October. These vibrant and pulsating times are finding eloquent manifestation in the art, literature and culture of the Soviet Union. The turbulent days, the tumultuous hearts, the enchanting dreams of millions of people of the resurgent land are likely to find thunderous echo in the hearts of the millions of Indian brethren - who will have a glimpse and a deep insight into the enchanting spiritual and cultural world of the people who are agog with new hopes, aspirations, yearnings, expectations, dreams and fantasies. The Festival of the USSR in India will definitely be a unique Odyssey about the cultural yearnings and treasures of our two peoples. Nothing could be more fascinating, more reassuring, more spectacular than the present cultural confluence for persons like me, who sincerely believe that our two peoples share immense nearness on both spiritual and cultural planes. The festivals of India and the USSR being organised in the two countries as part of festivities dedicated to the 70th anniversary of the Great October Socialist Revolution and 40th anniversary of the independence of India will be a giant step forward towards the meeting of minds and ethos of our two peoples.

\section{REFERENCES}

[1] I. K. Gorsky, "Alexander Vesyolovsky and Modern Times". M., Nauka, 1975; - P. 201.

[2] Introduction to V.M. Zhirmunsky, "Comparative literary criticism". Leningrad, 1979; - P. 6.

[3] A.N. Vesyolovsky, Bulletin of the Academy of Sciences of the USSR, Department of Social Sciences, 1936, No.3; - P. 384.

[4] G. Bongard-Levin and A. Vigasin, "The Image of India - The Study of Ancient Indian Civilization in the USSR". Progress Publishers, M., 1984.

[5] Y. Chelishev and A. Litman, "Tradition of Great Friendship". Raduga Publishers, M., 1985.

[6] A.P. Gnatyuk-Danilchuk, "Tagore, India and Soviet Union - A Dream Fulfilled". KLM Private Limited, Calcutta, 1986.

[7] A. Shifman, "Tolstoy and India". Sahitya Akademi, N. Delhi, 1969, 1978. (Translation from Russian by A.V. Essaulov).

[8] OP. Cit. under 4, P. 15.

[9] OP. Cit. under 5, P. 21.

[10] OP. Cit. under 4, P. 16.

[11] ibid, P. 17.

[12] ibid, P. 37.

[13] ibid, P. 38.

[14] ibid, P. 39.

[15] ibid, P. 41.
[16] See translation into Hindi by Sabir Siddiqui, "Volga ke darpan mein Ganga ke chitra". Rajkamal Prakashan, N. Delhi, 1987; - P.5.

[17] R.K. Megh, "Indian Journal of Russian Language, Literature and Culture", Vol. IV, No, 1-2, June-Sept. 1987; - PP. 69-81.

[18] A. Shifman, “Tolstoy and India”. Sahitya Akademi, 1978; - PP. 32.

[19] L.N. Tolstoy, Collected Works in 90 Volumes, Vol. 48; - P.11.

[20] A. Shifman, op. cit.; - P. 62

[21] ibid, P. 65.

[22] ibid, P. 67.

[23] ibid, P. 82.

[24] ibid, P. 103.

[25] ibid, P. 47.

[26] Y. Chellishev, op. cit.; - P. 206

[27] O. P. Bhatnagar, "October Revolution: Impact on Indian Literature" (Ed. Qamar Rais). Sterling Publishers, N. Delhi; - P. 76.

[28] K. Marx, F. Engels, Collected Works (in Russian), Vol. 23; - P. 10.

[29] O. Tumanyan, Selected Works in 2 volumes (in Russian), M., 1960; P. 252.

[30] P.N. Berkov, "Problems of the Historical Study of Literature". Leningrad, 1981; - P. 67.

[31] ibid.

[32] ibid.

[33] Quoted from the book cited under 27, P. 23.

[34] ibid., P. 32.

[35] Kaviraj Narahari, "October Revolution and National Liberaton Movement of a New Type". K. P. Bagchi \& Co., Calcutta, 1978.

[36] ibid., P. 32.

[37] Y. P. Chelishev, op. cit.; - P. 138.

[38] “October Revolution: Impact on Indian Literature”, op. cit.; - P. 64.

[39] ibid., P. 104.

[40] G. Lukacs, "Studies in European Realism". The Merlin Press, London, 1972.; - P. 223.

[41] ibid

[42] ibid. P. 109.

[43] ibid., P. 17.

[44] ibid., P. 19.

[45] Vishwanath Tripathi, op. cit. under 27, P. 2.

[46] ibid., PP. 54-55.

[47] Haldar Gopal, "October Revolution and India's Independence", Ed: Ali Asharaf and G. A. Syomin. Sterling Publishers, N. Delhi, 1977.; P. 209 